ISSN (print): 1698-6180. ISSN (online): 1886-7995

www.ucm.es/info/estratig/journal.htm

Journal of Iberian Geology 36 (2) 2010: 181-192

doi:10.5209/rev_JIGE.2010.v36.n2.6

\title{
The importance of microscopic examinations of eggshells: Discrimination of bioalteration and diagenetic overprints from biological features
}

\author{
Importancia de la microscopía en el examen de cáscaras de huevos: \\ discriminación entre bioalteración y señales diagenéticas de las \\ características biológicas
}

\author{
G. Grellet-Tinner ${ }^{1,2,3 *}$, F. Corsetti ${ }^{4}$, A.D. Buscalioni ${ }^{5}$ \\ ${ }^{1}$ Centro Associate Researcher at The Field Museum, Chicago IL, 60605, USA \\ ${ }^{2}$ Associate Researcher at The Journey Museum, Rapid City, SD, 57701, USA \\ ${ }^{3}$ Investigador Correspondiente, CRILAR - CONICET, Anillaco, Argentina \\ ${ }^{4}$ Department of Earth Science $\bullet$ University of Southern California, Los Angeles, CA 90089, USA \\ ${ }^{5}$ Departamento de Biología, Paleontología. Fac. Ciencias, Universidad Autónoma, Cantoblanco, 28049 Madrid, Spain \\ *Corresponding author: Gerald Grellet-Tinner, locarnolugano@gmail.com
}

Received: 20/12/09 / Accepted: 30/06/10

\begin{abstract}
Although fossilization usually favors the preservation of calcium carbonate biominerals, diagenetic alterations might still produce erratic patterns that overprint the original biological structures. This investigation tries to discriminate in the fossil record "pathological" eggshells from diagenetic induced features as well as determine their origin, and aims, when possible, to provide alternative parsimonious interpretations to the origin of some of these rare and erratic features. In the past, most dinosaur eggshell studies failed to combine cathodoluminescence, scanning electron microscopy, transmitted and polarized light microscopic observations and were limited to only one or several of these examinations, which might have contributed to misinterpretations by lack of thorough observations. Sauropod eggshells from Faidella (Spain) and Auca Mahuevo (Argentina) provide ideal proxies to perform this research, as they display aberrant crystallographic features that have been or could be considered pathological. Under cathodoluminescence, the specimens fluoresce tremendously, indicating a strong diagenetic component in their make up. Guided by this information, further transmitted and polarized light microscopic examinations reveal microscopic dissolution fronts, which otherwise would have been left unnoted. The proposed hypothesis for the Faidella specimens is that organic filaments, which represent up to $2 \%$ of the shell composition, were exposed on the internal wall surfaces of pore canals where the calcium carbonate had been dissolved during a
\end{abstract}


first diagenetic event. As such, the exposed extremities of the organic filaments likely triggered the formation of pseudo cores that mimic those in the membrana testacea during oogenesis. Observations based on the Argentinean specimens indicate that an added extra external structural layer is also separated from the original biological eggshell by a dissolution and recrystallization front. In addition to this abiotic process, artifact formations induced by bacterial mediation, a topic treated in an earlier publication, was also common at Auca Mahuevo. Without combined microscopic and cathodoluminiscence observations, the Faidella and Auca Mahuevo megaloolithid eggshells could be easily considered pathological eggshells. This would bias ensuing phylogenetic, paleobiological, and paleoenvironmental interpretations.

Keywords: microscopic characterization, dinosaur eggs, diagenesis, pathological eggshells

\section{Resumen}

A pesar de que la fosilización favorece la conservación de los biominerales de carbonato cálcico, las alteraciones diagéneticas pueden llegar a producir patrones erráticos que se sobrepongan a las estructuras biológicas originales. Esta investigación intenta discriminar en el registro fósil cáscaras "patológicas" con rasgos diagenéticamente inducidos, determinando su origen y procura, en la medida de lo posible, dar una interpretación parsimoniosa alternativa al origen de algunos de estos rasgos extraños y erráticos. En el pasado, la mayoría de los estudios en cáscaras de dinosaurios se vieron limitados al uso de uno o dos de estos procedimientos (catodoluminiscencia, microscopía electrónica, observaciones con microscopio de luz transmitida y polarizada), lo que puede haber contribuido a interpretaciones erróneas debido a observaciones incompletas. Las cáscaras de huevos de saurópodos del yacimiento de Faidella (España) y de Auca Mahuevo (Argentina) muestran condiciones ideales para realizar esta investigación, ya que denotan rasgos cristalográficos aberrantes que habían sido o podrían ser considerados como patológicos. Mediante catodoluminiscencia, los ejemplares muestran una violenta fluorescencia, lo que indica un fuerte componente diagenético en su composición. Guiados por esta información, los análisis posteriores con microscopía de transmisión y luz polarizada revelan frentes de disoluciones microscópicas, que de otro modo no habrían sido apreciadas. La hipótesis que se propone para los ejemplares de Faidella es que filamentos orgánicos, que representan hasta el $2 \%$ de la composición de las cáscaras, estaban expuestos en las superficies de las paredes internas de los canales de los poros donde el carbonato cálcico se hubo disuelto durante el primer evento diagético. Dada esta condición, los extremos de los filamentos orgánicos expuestos, muy probablemente dispararon la formación de pseudo núcleos que imitan los de la membrana testácea durante la oogénesis. Las observaciones basadas en los ejemplares argentinos indican que una capa externa extra está separada de la cáscara biológica original por una disolución y recristalización. Además de este proceso abiótico, en Auca Mahuevo son también frecuentes rasgos inducidos por bacterias, asunto tratado en una publicación anterior. Sin la combinación de la combinación de estos métodos, las cáscaras de huevo de Faidella y Auca Mahuevo podrían haber sido fácilmente consideradas como patológicas, lo que sesgaría otras interpretaciones como las filogenéticas, paleobiológicas y paleoambientales.

Palabras clave: caracterización microscópica, huevos dinosaurios, diagénesis, cáscaras patológicas

\section{Introduction}

Solid archosaur eggshell consists of laterally juxtaposed calcium carbonate crystals (aragonitic for chelonians or calcitic for archosaurs) (Erben, 1970; Packard and DeMarco, 1995) on an organic network (Kohring and Reitner, 1996; Packard and DeMarco, 1995), regularly grouped in eggshell units that nuleate from an underlying membrana testacea (MT) in Dinosauria (Pooley, 1979, Mikhailov, 1992). Oogenesis is a complex and genetically controlled process that occurs in the shell gland. It consists of a series of successive ontogenetic events that peaks with mobilization of calcium carbonate salts to form the solid eggshell. For dinosaurians, a ring of small (spherulitic) calcitic crystals encircles the nucleation centers on the protein-rich MT during that last phase. These crystals are subsequently surrounded by larger crystals that grow laterally and outward to form the eggshell, as the downward expansion of these larger crystals is precluded by the presence of the organic membrana testacea (Packard and DeMarco, 1995).

The eggshell thickness and structure is clade specific (Ar et al., 1974; Grellet-Tinner, 2006). In primitive reptilians, it consists of a single layer of crystals with a vertical and unidirectional C-axis, termed here "layer 1". Throughout the phylogenetic evolution of saurischian dinosaurs, the eggshell structure evolved from a monolayered in primitive sauropods to a tri-laminated structure in avians (Grellet-Tinner and Chiappe, 2004; GrelletTinner et al., 2006), where the C-axis of the crystals of layer 2 is orthogonal or nearly so, to the innermost layer. Layer 3 (the outer-most layer), presently only known in primitive birds and their descendants (Grellet-Tinner and Chiappe, 2004; Grellet-Tinner et al., 2006), has a different orientation with respect to the adjacent layer 2. The cross-sectional crystal habits of theropod eggshells are equally noteworthy. The crystals of layer 1 form a fanlike feature that extends to the outer eggshell surface or 
abuts the second layer. These crystals are acicular in the mono-layered shell of sauropods (Grellet-Tinner et al., 2004, Grellet-Tinner et al., 2006), and in layer 1 of allosaurid tetanurians (pers. obs.), oviraptorids (GrelletTinner and Chiappe, 2004), Deinonychus antirrhopus (Grellet-Tinner and Makovicky, 2006), but evolve into blade-shape crystals in birds (Grellet-Tinner et al., 2006; Grellet-Tinner and Norell, 2002). Remarkably, this phylogenetic evolution of eggs and their eggshell structures parallels the ontogenetic formation of eggshell in modern birds (Deeming and Ferguson, 1995), contra Zeletnitsky and Therrien (2008).

The eggshell thickness and the distribution of pore canals in the eggshell are also clade specific and additionally good indicators of nesting environments (Board and Sparks, 1995; Cousin, 1997; Cousin and Breton, 2000; Grellet-Tinner et al., 2004). Oogenesis in extant avians and reptiles combined with observations of eggs and eggshells in the fossil record, which are positively identified, creates a reasonable template facilitating, a priori the differentiation of crystallographic artifacts from biological features.

Although fossilization usually favors the preservation of calcium carbonate over some other natural materials, diagenetic processes might obscure the original crystal structures and produce erratic patterns that overprint the original biological structures, rendering them confusing, or worse, misleading. These patterns, if misconstrued, could foster erroneous paleobiologic, paleoenvironmental, and phylogenetic interpretations. Our analysis is particularly well-suited to address the "pathologic" eggshell concept, which has recently received some attention. Although rare in the fossil record (Kerourio, 1981), pathological eggshells are thought to form as aberrations rejected by the host organism (Jackson et al., 2004), and contain an unusual high number of structural and crystallographic artifacts (Jackson and Varriccchio, 2003).

The goal of this investigation is to apply combined examinations of cathodoluminescence, scanning electron microscopy, TLM, EDS, and PLM (see Technical abbreviations) examinations to help identify diagenetic overprinting in eggshells, particularly in the case of pathological eggshells. Modern eggshells, known to lack any diagenetic overprinting, form a control group. Two sets of Late Cretaceous specimens will be considered, one from Faidella (Spain) and the other from Auca Mahuevo (Argentina); each displays aberrant and unusual crystal structures that have been or could be viewed as so-called pathologic eggshells. The aims of this investigation are to add cathodoluminescence to the arsenal of microscopic analytic tools to evaluate the origin of aberrant micro- structures in the Faidella and Auca Mahuevo megaloolithid eggs and offer the most parsimonious interpretations to the origin of rare and erratic structural features, when possible.

\section{Materials and Methods}

\subsection{Abbreviations}

Institutional abbreviations- UPUAM, Unidad de Paleontología, Universidad Aut' noma de Madrid.

Technical abbreviations- BSEM, backscattered scanning electron microscopy; DPI, dots per inches; EDS, energy-dispersive X-ray spectroscopy; PLM, polarized light microscopy; SEM, scanning electron microscopy; TLM, transmitted light microscopy, MT, membrana testacea.

\subsection{Eggshell Material}

Although we do not adhere to the parataxonomic classification as its groups have been shown to be not natural (paraphyletic and polyphyletic) and their members unstable as their inclusions were based on very few and weighted character, we nevertheless use the parataxonomic megaloolithid oofamily name as a mean of communication and bridging the old literature with this research. Specimens are housed at the Universidad Autonoma de Madrid under UPUAM numbers from UPUAM 20 to UPUAM 30.

\subsection{Experimental design}

\section{Cathodoluminescence (CL)}

$\mathrm{CL}$ is a well-known technique applied in carbonate sedimentology and is most commonly used to help identify areas of alteration in previously precipitated calcium carbonate (see Tucker and Wright, 1990, for an excellent description of the theories and methods of CL). Pure $\mathrm{CaCO}_{3}$ has very little if any luminescence, and is commonly taken as a qualitative baseline for non-luminescence. To be clear, unaltered $\mathrm{CaCO}_{3}$ is not perfectly black under CL examination but changes in luminescence in $\mathrm{CaCO}_{3}$ are observed when ionic substitutions take place in the crystal lattice (Amthor, 1993; Barbin, 2000). When $\mathrm{Mn}^{2+}$ substitutes for $\mathrm{Ca}^{2+}$, even in trace amounts of only a few parts per million, a bright luminescence is observed. In contrast, incorporation of $\mathrm{Fe}^{2+}$ quenches luminescence (even lower than baseline, to produce a "black" luminescence), but substantially more $\mathrm{Fe}^{2+}$ is needed to achieve this effect versus $\mathrm{Mn}^{2+}$, on the order of 1000's of parts per 
million (Amthor, 1993; Barbin, 2000). As a general rule, diagenetic fluids are enriched in $\mathrm{Mn}^{2+}$ and $\mathrm{Fe}^{2+}$ versus the original biological host fluid, which are commonly devoid of free $\mathrm{Mn}^{2+}$ and $\mathrm{Fe}^{2+}$. Thus, the CL technique is quite good at identifying altered areas of originally pure calcite that would otherwise be invisible to the naked eye or petrographic microscope. In order to confirm that eggshells conform to conventional wisdom with respect to $\mathrm{CL}$, we examined extant emu eggs under CL. Thin sections revealed a pristine crystalline structure under transmitted light and, as expected, the extant emu eggshells displayed the characteristic non-luminescence associated with unaltered samples. From this experiment, we assume that luminescence in eggshells would likely be the result of post-depositional alteration.

Much of the previous work on eggshells utilized the SEM to examine the number and crystal orientation of the layers; thus, we first examined and described the specimens via SEM. The samples were then thin sectioned and characterized with a petrographic microscope under transmitted and polarized light, where new taxonomically useful features became apparent. Then, the samples were examined under CL, to determine the presence or absence of structures not visible under SEM or plane light analysis. Finally, the samples were reexamined using the SEM in backscatter mode (BSEM), in an attempt to determine the relative presence of $\mathrm{Fe}^{2+}$ in the $\mathrm{CaCO} 3$ lattice.

\section{Study sites}

\subsection{Faidella, Spain}

The Upper Cretaceous and lowermost Paleocene deposits of South-central Pyrenees (Northern Spain) have yielded abundant palynological, macrophytes and vertebrate sites, the latter containing bones, eggs, and ichnite assemblages. The Faidella site, dated as Uppermost Campanian, sits within the Tremp Formation and is located at the East Tremp syncline (López Martínez, 2000; Bravo et al., 2000). This egg-bearing locality has been described as a recurrent nesting area containing several superposed levels with scattered autochthonous clutches from Megaloolithus siruguei ootaxon (López Martínez, 2000; Bravo et al., 2000). Nine megaloolithid egg clutches were recovered in sandstone channels from continental deposits of fluvial or deltaic floodplains origins (Bravo et al. 2000). Eggshells are covered with an ubiquitous secondary calcite on both inner and outer surfaces (Bravo et al. 2000). According to Bravo et al. (2000), the eggshell thickness ranges from 2.3 to $3.8 \mathrm{~mm}$ and is vertically crossed by straight or bifurcated pore canals between the eggshell units. Each node of the nodular outer surface of the eggshell forms the termination of an eggshell unit (Fig. 1). SEM and TLM observations of the Faidella eggshells show that each eggshell unit consists in its entirety of vertically oriented acicular calcite crystals that originate from a nucleation center at the base of each eggshell unit. More importantly, radiate crystal bundles (spherulites) that mimic the nucleation centers at the base (Fig. 1) are found throughout the eggshell (unreported by the original authors). These ubiquitous features, observed in both TLM and SEM views, range in diameter from 94 to 131 microns, which compare favorably with the 110 micron average value noted for the nucleation centers at the base of the eggshells. When observed in SEM, they display a similar crystallographic habit to their biological counterparts at the base of the eggshell. The combined microscopic observations confirm that the radiating structures are real features in the eggshell (Fig. 1) and not artifacts of a given method of observation (SEM or TLM). Nucleation centers are normally exclusively found only at the base of the eggshell units regardless of the saurischian dinosaur egg type, so their occurrence in the entire eggshell thickness is unusual and warrants further CL investigation. Are these truly pathogenic eggs, as could be surmised by some workers (Jackson and Varricchio, 2003; Jackson et al., 2004), or are they diagenetic artifacts?

\subsection{Interpretation of the Faidella megaloolithid eggshell}

Nucleation centers consist of organic cores with calcium carbonate accretions around them, all acquired during early stage of eggshell formation. The cores consist of optimal and predetermined concentrations of protein on some loci in the upper region of the MT that will trigger the growth of the primary spherulites in the shell gland of dinosaurs (Packard and DeMarco, 1995). The small calcite crystals of the primary spherulites form a typical circular rosette in the upper section of the MT, as its protein hyper-concentration prohibits a downward crystallization (Packard and DeMarco, 1995). As instances of "pathological" eggshells (Jackson et al., 2004) have been reported in the literature associated with megaloolithid egg species (Vianey-Liaud et al., 1994), the Faidella eggshells were closely examined under CL and then reexamined with TLM. In general, the entire eggshell sections display a tremendous fluorescence under CL (Fig. 2) indicating a strong diagenetic component in their make up, which could be expected by the presence of diagenetic calcite on both surfaces of the eggshell as correctly noted 

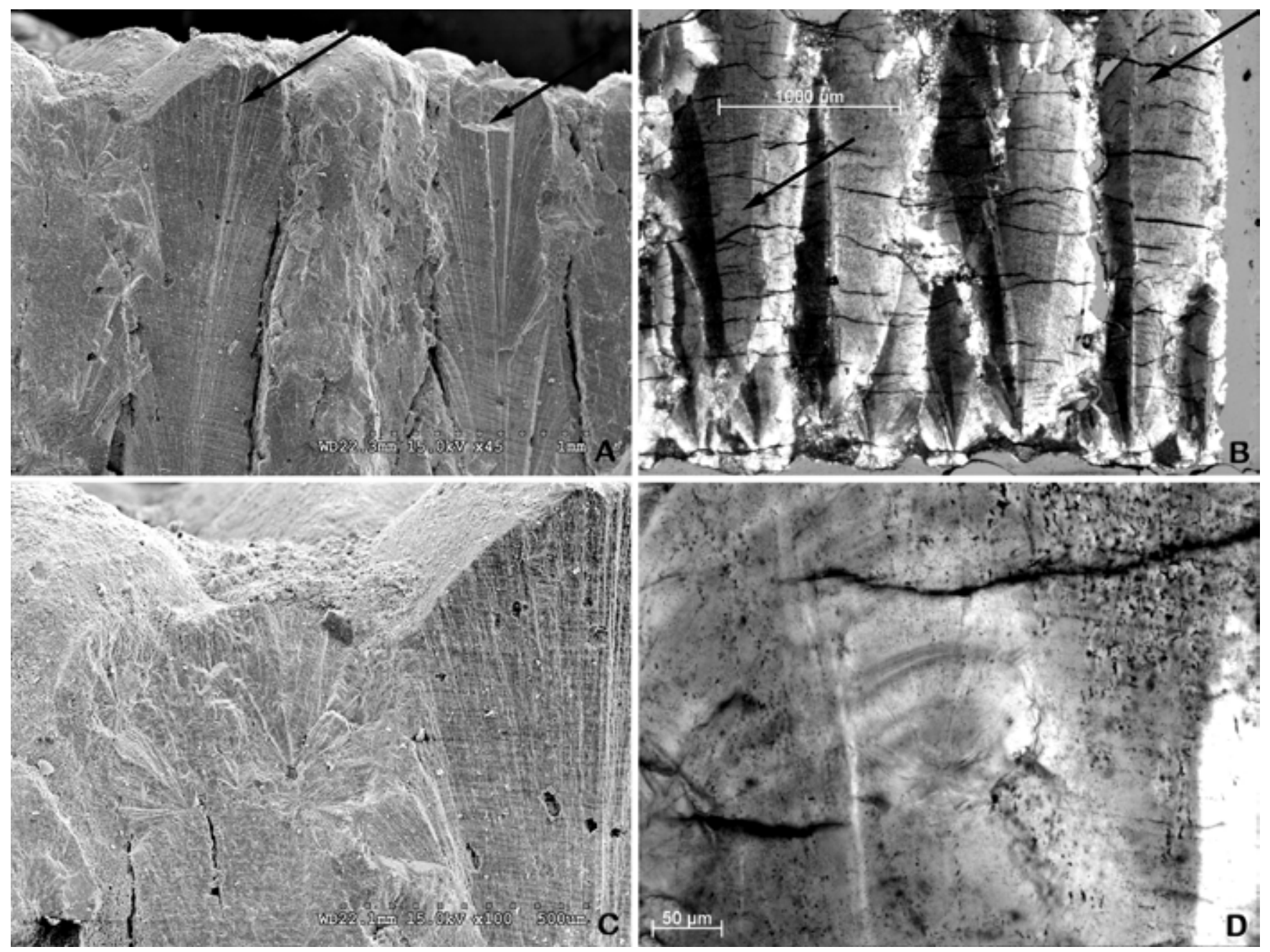

Fig. 1.- $\quad$ A and B. SEM and TLM images respectively of Fadailla sauropod eggshells. Black arrows indicate eggshell units and their nodular outer surficial extremities. Note in A, the acicular crystallization, also observed in Auca Mahuevo specimens, and in B, the weak lines that cross at right angle the longitudinal axis of the eggshells are remnant of the organic matrix ( $2 \%$ of the eggshell). These lines are much thinner than the parallel thick black lines. C and D. SEM and TLM images respectively of radiate crystal bundles (spherulites) that mimic the nucleation centers normally observed at the base of eggshell units. These ubiquitous features, observed in both TLM and SEM views, range in diameter from 94 to 131 microns, values that compare favorably with the nucleation centers.

Fig. 1.- A y B. Imágenes del SEM y TLM respectivamente de las cáscaras de saurópodos de Faidella. Las flechas negras indican unidades en la cáscara y sus extremos nodulares externos. Nótese en A la cristalización acicular, que también se observa en Auca Mahuevo. En B, las líneas tenues que cruzan en ángulo recto el eje longitudinal de las cáscaras, son remanentes de la matriz orgánica (2\% de la cáscara). Estas líneas son mucho más finas que las líneas negras paralelas. C y D. Imágenes SEM y TLM respectivamente que muestran los paquetes radiales de cristales (esferulitos) los cuales imitan los núcleos normalmente observados en la base de las unidades de las cáscaras. Estas características ubicuas, observadas tanto en TLM como SEM, oscilan entre 94 y 131 micras de diámetro, valores que son positivamente comparables con los centros de nucleación.

by the previous authors (Bravo et al. 2000). Furthermore, large sections of the eggshell are crisscrossed vertically by brightly luminescent zones, predominantly at the emplacement of pore canals and apertures, and at the outer tip of the eggshell units where those have been dissolved. With this search image in mind, a closer TLM examination of one of these features reveals a microscopic dissolution front at the level of its maximum lateral expansion and the original calcitic material of the eggshell (Fig. 2).
The luminescence demonstrates a strong diagenetic component. The abnormal structures, although superficially resembling the loci and spherulites of unaltered shell units, should not be confused as such. We hypothesize that the similarities between the biological and diagenetic features are caused during the burial of the egg in the sediments with a hypersaturated calcitic solution that infiltrated every natural openings of the eggshell. In fact, the geochemical composition of the Faidella egg- 

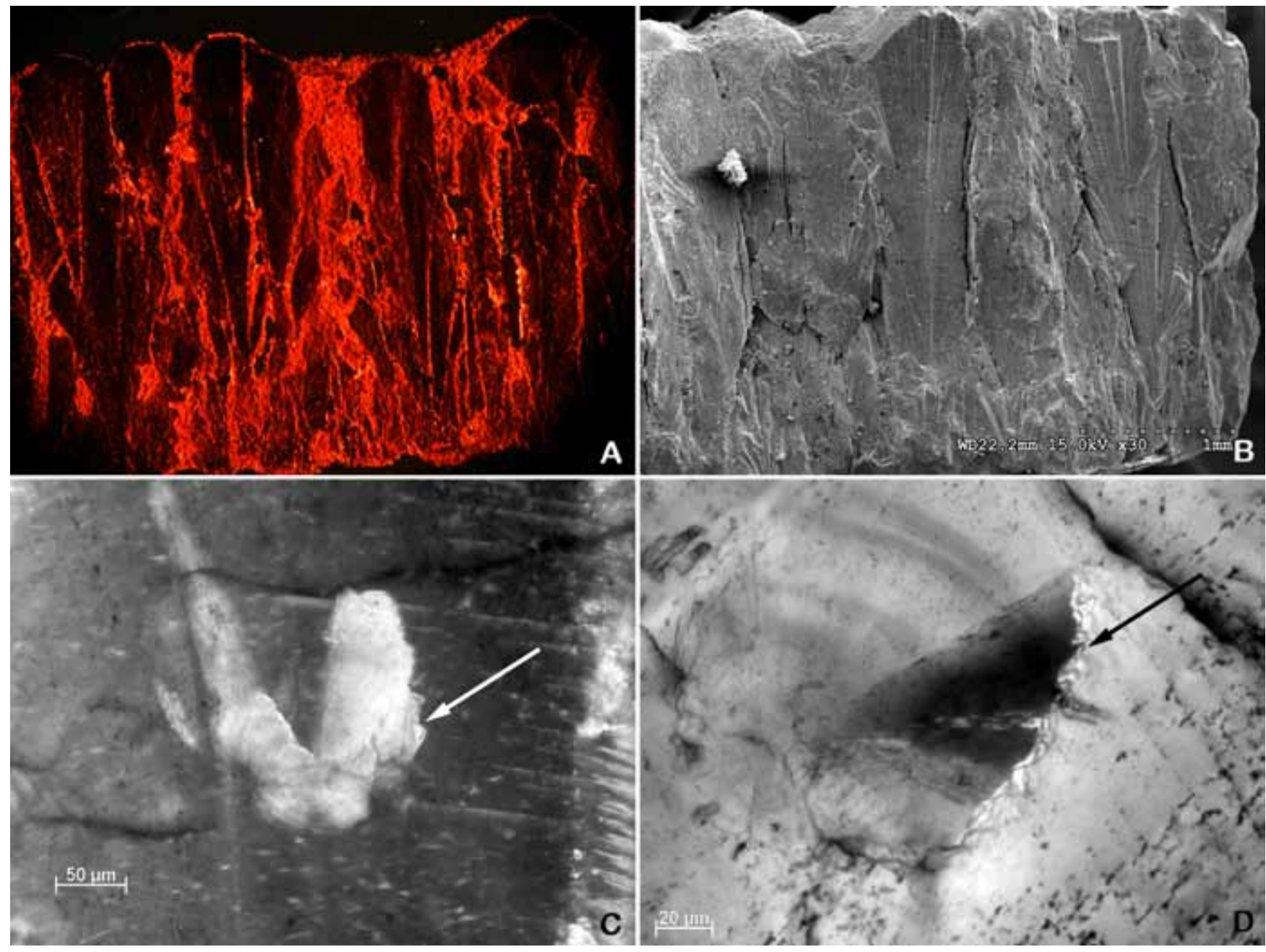

Fig. 2.- $\quad$ A and B. CL and SEM images respectively. The entire eggshell sections display a tremendous fluorescence under CL indicating a strong diagenetic alteration, which is congruent with the presence of diagenetic calcite on both surfaces of the eggshell as noted by Bravo et al. (2000). Note that the strongest CL reaction occurs in between eggshell units rather than within the units themselves, although present. This positively correlates with the invasion and recrystallization of calcitic material. $\mathbf{C}$ and $\mathbf{D}$. TLM images of two radiate crystal bundles. Arrows point to the dissolution edges of these erratic features. Combined CL and detailed TLM observations demonstrate that these structures are abnormal but not pathogenic.

Fig. 2.- A y B. Imágenes CL y SEM respectivamente. Las secciones de las cáscaras muestran una notable fluorescencia bajo CL, indicando fuerte alteración diagenética y que es congruente con la presencia de calcita diagenética en ambas superficies de la cáscara tal y como hizo notar Bravo et al., (2000). Nótese que la reacción más violenta con la CL se da entre unidades en la cáscara en lugar de dentro de las propias unidades, aunque en ambos casos hay reacción. Esto se correlaciona positivamente con la invasión y recristalización de material calcítico. C y D. Imágenes TLM de dos paquetes radiales de cristales. Las flechas señalan los márgenes de disolución de estos rasgos erráticos. El uso combinado de CL y un detalle de TLM demuestran que estas estructuras son anormales pero no patológicas.

shells revealed no significant differences in the amounts of major and traces elements with extant eggshells. When compared with in situ sediments (Bravo et al., 2003), a significant increase in $\mathrm{Sr}$ is found (between 2.000 and 2500 ppm for eggshells and $1057 \mathrm{ppm}$ for the sediment). The increase in Sr is directly related with the Ca substitution during fossil diagenesis. Organic components are an intimate component of eggshell (Board and Sparks, 1995) and horizontal and parallel lines in dinosaur eggshell are the remnants of these proteins. They abut at the internal surface of the wall of a pore canal when the cal- cium carbonate is dissolved during diagenesis and their extremities could trigger the formation of the pseudo cores like the loci in the MT during oogenesis. Whether the origin of the dissolved calcite solution was from pore fluids or the product of an earlier dissolution of the nodes and other eggshell structures is left open for debate, and whether the deposition process was purely chemical or bacterially bio-mediated is beyond the scope of this research. Regardless of these considerations, it appears that the growth of the crystallographic artifacts initiated from eggshell organic compounds produced crystallo- 
graphic structures that could only be differentiated from their biological counterpart by combined CL and other microscopic examinations. Without these observations, the Faidella megaloolithid eggshells could have easily been considered pathological eggshells, even worse, the presence of nucleation center like features throughout the eggshell could have been used as a taxonomic character.

\subsection{Auca Mahuevo, Argentina}

Interestingly, the eggshell of the megaloolithid eggs found in Faidella, Spain (Bravo et al., 2000) and Auca Mahuevo, Argentina, (Grellet-Tinner et al., 2004) share many structural characters. In many respects, the Late Campanian Auca Mahuevo egg-bearing locality represents a unique paleontological setting that could be regarded as a Lagerstätte (Bottjer et al, 2002; Grellet-Tinner, 2005), as it has produced embryos in ovo (Chiappe et al., 2001), endocasts of the embryonic skin and MT (Chiappe et al., 1998; 2000; Grellet-Tinner, 2005). This locality offers extensive outcrops on four stratigraphic levels where dinosaur eggs and eggshell fragments are so abundant that the notion of "walking on eggs" (Chiappe and Dingus 2001) is entirely justified. Although eggs are present in all four stratigraphic levels, level 3 (Chiappe et al., 2000) has been the most prolific and easily studied, as its erosional surfaces extend over $8 \mathrm{~km}^{2}$. The studied eggshell material originates from stratigraphic level 3 (Chiappe et al, 2000; and see Grellet-Tinner et al., 2004, for a detailed description of the eggs and eggshells from this locality and Grellet-Tinner, 2005, for biomediation of the MT). A few specimens display an extra external structural layer that strongly resembles the top-most section of normal titanosaurid eggshells (Fig. 3). The thin sections for this study, including those with preserved MT, display an ubiquitous luminescence at the fringe between the outermost portion of the "normal" eggshell and the extra eggshell components that cap the eggshell below (Fig.3). Red luminescence is present in the eggshell and in the endocast of the MT, indicating an evident diagenetic alteration of both the organic and inorganic components of these eggshells. Whether the diagenetic alteration was limited to an ionic/molecular replacement with biomediation or was strong enough to remodel the architecture and chemical make up of the observed specimens remains unclear.

\subsection{Interpretation of the Auca Mahuevo eggshell}

The red luminescence indicates that chemical alteration had occurred in few Auca Mahuevo eggshells. Sch- weitzer et al. (2005) report molecular chemistry from these eggshells, yet, our analysis would suggest that caution should be exercised when interpreting the chemical data, because the CL signature clearly indicates the postdepositional movement of fluids through these structures and recrystallization that has been biomediated in several occasions (Grellet-Tinner, 2005). A number of these eggs from Auca Mahuevo were recently diagnosed as pathological by Jackson et al. (2004). However, Jackson et al. (2004) did not mention examination of their specimens under CL to determine whether diagenetic events could have participated to the erratic structural and crystallographic patterns they described. Before considering the proposed field of observations alone, it becomes unclear whether a grouping of eggs in a clutch represents the product of one gravid female during one season, or the mixture of multiple unhatched or infertile ovidepositions from many females over several reproductive seasons. Hence, the criterion of abnormality with associated pathological eggshells for eggs based on their topmost position in titanosaurid clutches as proposed by Jackson et al. (2004) becomes strongly equivocal as this spatial arrangement contradicts the observations of Ewer et al. (1984), who suggest that the few abnormal eggs of extant batagurine turtles are located at the bottom of their clutch being the first ones to be oviposited. Furthermore, Jackson et al. (2004) rightfully noted a "blue-green halo outlines the exposed eggs indicating chemical reduction of the sediment immediately surrounding the egg, possibly the result of decomposition of the content after burial" (p. 915) and reported "authigenic analcime" (p. 917) in eggshells. It is well known that bacteria preferentially feed on organic matter before attacking inorganic compounds (Hayward et al., 1989, 1991), thus the decomposition of egg content after burial is well within the realm of bacterial activities and such sediment coloration was noted and considered as the product of bacterial colonies (Fig. 4) by GrelletTinner (2005). As a parenthesis, according to Bravo et al. (2003), the timing of such biomediation takes place at early stages of egg burial, as the presence of halos of organic matter or the release of organic matter occurs during the first week in sands but after the first month in marls (Bravo et al., 2003). Prima-facie, contrary to biological pathologies (Jackson et al., 2004), both observations made by these authors support a strong diagenetic component in the sediments and these eggshell make up, which is congruent with our CL reaction. Moreover, three types of pathologies in different eggs in a single clutch and within one egg were reported (Jackson et al., 2004). The latter seems biologically inconsistent 

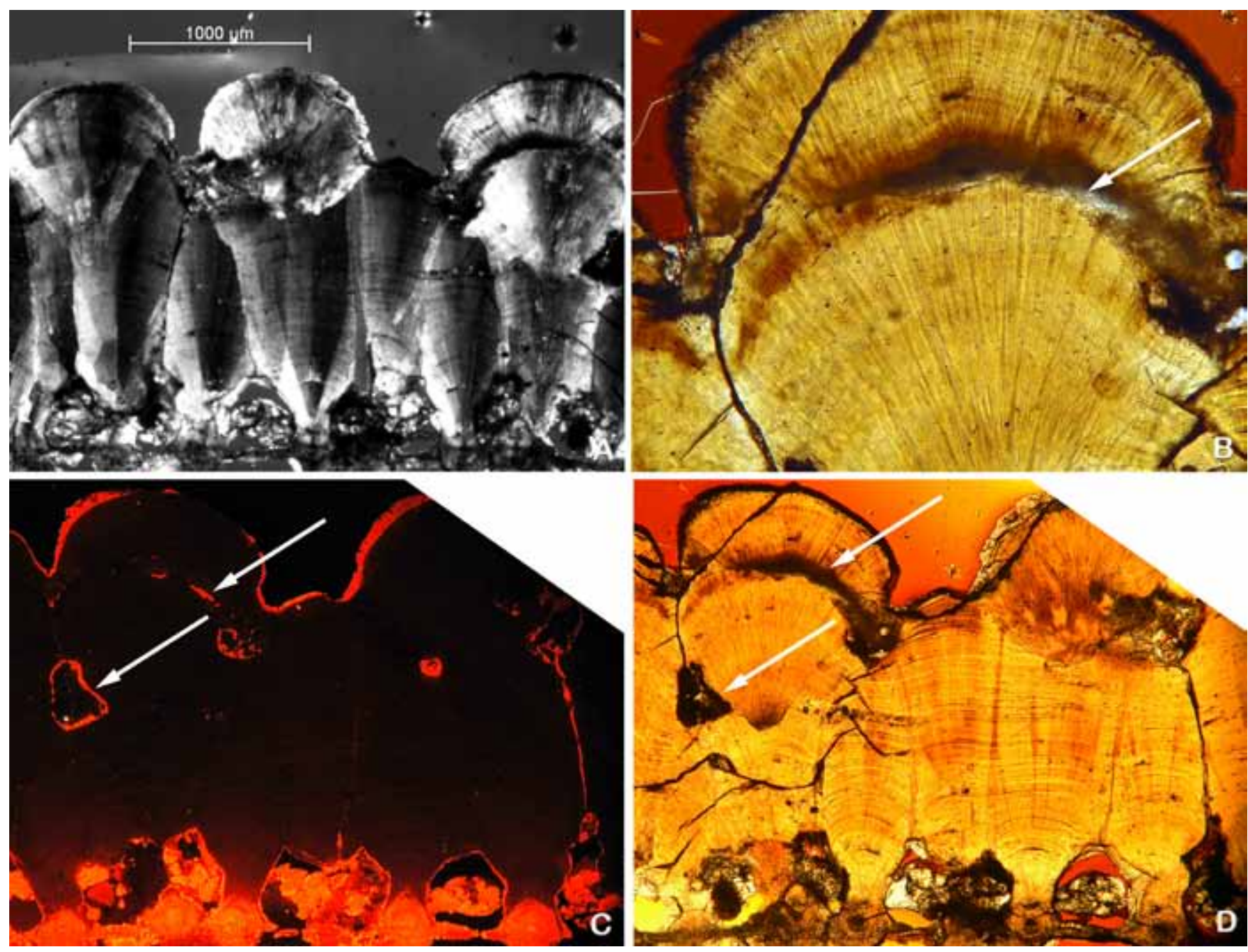

Fig. 3.- A. TLM images of an Auca Mahuevo abnormal eggshell. Note the "pathological" aspect, per Jackson et al. (2004), expressed by a second nodular eggshell layer atop the original shell. B. Higher magnification of one of these abnormalities. Arrow points to a dissolution edge at the contact of the extra layer and the original biological counterpart. C and D. CL and TLM images, respectively, of the same eggshell sections. Arrows point to the few features indicating the zones of diagenetic recrystallization that "cement" both eggshells. Whether bound together through chemical or bio-mediated processes remains to be elucidated.

Fig. 3.- A. Imágenes TLM de una cáscara anormal de Auca Mahuevo. Nótese el aspecto "patológico", según Jackson et al. (2004), tal y como muestra la presencia de una segunda capa nodular en la zona externa de la cáscara. B. Una de estas anormalidades vista en aumento. La fecha señala el margen de una disolución en el contacto entre la capa extra y la capa biológica original. C. y D. Imágenes CL y TLM respectivamente de las mismas secciones de la cáscara. Las fechas señalan los rasgos sutiles de las zonas de recristalización diagenética que "cementan" ambas zonas de la cáscara. No se puede especificar si estas capas extra se han producido por procesos químicos o por mediación biológica.

with the shell production by female titanosaurids, which generate eggs in mass like modern crocodilians and unlike avians that are monoauthochronous ovidepositors. In addition one, two, and three different pathological eggshell layers present in a single egg, as stipulated, is beyond biological wisdom. Conversely, the presence of multiple eggshell abnormalities in the same clutch due to various degrees of erosion of eggshell structures and ensuing $\mathrm{CACO} 3$ remobilization is more consistent with our present knowledge of chemical and bacterial mediation in extant eggs (Hayward et al., 1989, 1991). Such acidification and bacterial alteration result in a first stage in the destruction of the surficial eggshell ornamentations (Fig. 4), increase in size of pore canals and apertures, among other artifacts, all visible under microscopic examinations (Hayward et al., 1989, 1991). In a second stage, the dissolved calcium carbonate is mobilized and precipitated either chemically or through biomediation. It can then act as cement between previously eroded structures. The studied pathological eggshell falls well within this category, as a clear dissolution edge is visible at the junction between the underlying normal eggshell structure and the extra eggshell structural elements, thus refuting completely the pathological argument. 

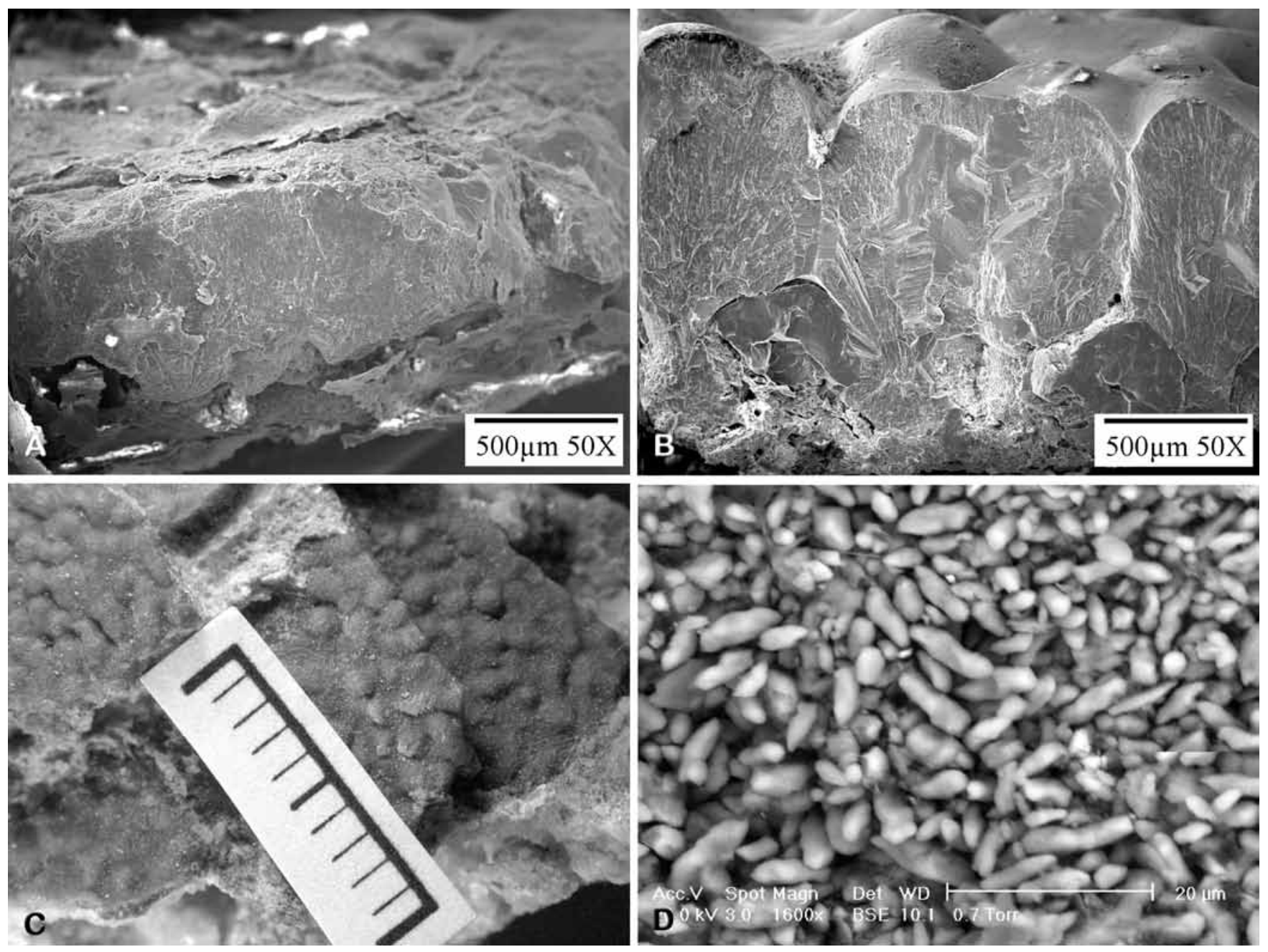

Fig. 4.- A and B. SEM images of an Auca Mahuevo eggshell from one egg clutch that show various degrees of alteration. Note the extreme morphological differences between samples A and B as much in their surficial than cross-sectional aspects. C. Eggshell fragments are randomly stacked and cemented together during several and successive taphonomic processes. D. Evidence of bacterial mediation during at least one taphonomic stage (Grellet-Tinner, 2005). Presence of bacteria and fossilized membrana testacea (MT) advocate that the process occurred during the first month of burial (Bravo et al., 2003).

Fig. 4.- A y B. Imágenes SEM de una cáscara que muestra diferentes grados de alteración procedente de una puesta de Auca Mahuevo. Nótese las diferencias morfológicas extremas entre la muestras A y B tanto en su superficie como en su sección transversal. C. Los fragmentos de cáscara se apilan azarosamente y se han cementado a lo largo de sucesivos procesos tafonómicos. D. Evidencia de la mediación bacteriana durante al menos un estadio tafonómico (Grellet-Tinner, 2005). La presencia de bacterias y de membrana testácea (MT) sugiere que el proceso ocurrió durante el primer mes de enterramiento (Bravo et al., 2003).

\section{Discussion}

In view of the difficulties to discriminate biological from diagenetic features in dinosaur eggshells, we suggest a series of investigative procedures that we summarize in Table 1. In addition, it would seem reasonable to classify the eggshells with erratic or aberrant structural features only as abnormal eggshells until they are submitted to a rigorous analytic and testing procedure. According to whether the studied specimen fails or pass the testing process, it be will regarded either as a diagenetic by-product or a true biological (Fig. 5), thus pathologi- cal, aberration. Regardless of the outcome, much will be gained by understanding diagenetic processes, their sequences and respective timing in concert with the local sedimentology and geology, or pathologies, which potentially reflects several paleobiological, paleoenvironmental, and/or taxonomical drivers. In respect with paleobiology, reptiles that ovideposit pathological eggshells severely decrease, by the nature of the aberrant eggshell morphology, the chances of bringing future generations to life. In terms of paleoenviromental inferences, it is well recognized that certain chemical or excess stress delay ovideposition by egg resorbtion and reshelling or simply 


\begin{tabular}{|c|c|c|c|}
\hline $\begin{array}{l}\text { STRUCTURAL } \\
\text { OBSERVATIONS }\end{array}$ & CL OBSERVATIONS & $\begin{array}{l}\text { SUGGESTED } \\
\text { OBSERVATIONS }\end{array}$ & $\begin{array}{l}\text { POSSIBLE } \\
\text { CONCLUSIONS }\end{array}$ \\
\hline $\begin{array}{l}\text { No noticeable } \\
\text { abnormalities }\end{array}$ & No luminescence & $\begin{array}{l}\text { Confirmed with BEM } \\
\text { for possible presence of } \\
\text { quenching iron ions. }\end{array}$ & $\begin{array}{l}\text { No diagenetic alteration. Eggshell structure } \\
\text { is phylogenetically, paleobiologically, and } \\
\text { paleoenvironmentally ( } 3 \text { Ps) informative. }\end{array}$ \\
\hline $\begin{array}{l}\text { No noticeable } \\
\text { abnormalities }\end{array}$ & $\begin{array}{l}\text { Luminescence pres- } \\
\text { ent in fine parallel lines } \\
\text { throughout the eggshell or } \\
\text { underlying MT }\end{array}$ & $\begin{array}{l}\text { BEM to estimate a possible } \\
\text { diagenetic alteration in the } \\
\text { rest of the eggshell. }\end{array}$ & $\begin{array}{l}\text { Diagenetic alteration limited to proteinous ma- } \\
\text { trix likely bacterially bio-mediated or induced. } \\
\text { Eggshell structure is still } 3 \text { Ps informative. } \\
\text { Possible diagenetic implications in respect } \\
\text { with burial and bio-mediated diagenetic tim- } \\
\text { ing. }\end{array}$ \\
\hline $\begin{array}{l}\text { Surficial and pore } \\
\text { channels second- } \\
\text { ary deposits }\end{array}$ & $\begin{array}{l}\text { Luminescence in pore } \\
\text { channels and eggshell } \\
\text { outer surfaces }\end{array}$ & $\begin{array}{l}\text { BEM to estimate a possible } \\
\text { diagenetic alteration in the } \\
\text { rest of the eggshell. }\end{array}$ & $\begin{array}{l}\text { BEM does not show iron replacement. } \\
\text { Eggshell structure is still } 3 \text { Ps informative. } \\
\text { Diagenesis was limited to surface and pore } \\
\text { deposition and crystallization. Diagenetic } \\
\text { implications. }\end{array}$ \\
\hline $\begin{array}{l}\text { Surficial and pore } \\
\text { channels second- } \\
\text { ary deposits }\end{array}$ & $\begin{array}{l}\text { Luminescence in pore } \\
\text { channels and eggshell } \\
\text { outer surface and ab- } \\
\text { normal line structures } \\
\text { between natural eggshell } \\
\text { structural layers } \\
\text { Implication for abnormal } \\
\text { eggshell structure, i.e. ad- } \\
\text { ditional structural layers, } \\
\text { separation of structural } \\
\text { layers by thin allotautho- } \\
\text { tonic elements. }\end{array}$ & $\begin{array}{l}\text { Check in SEM and TLM } \\
\text { for possible dissolu- } \\
\text { tion fronts and EDS to } \\
\text { determine the elemental } \\
\text { composition of diagenetic } \\
\text { lines between the eggshell } \\
\text { structural layers. BEM to } \\
\text { estimate a possible diage- } \\
\text { netic alteration in the rest } \\
\text { of the eggshell. }\end{array}$ & $\begin{array}{l}\text { Diagenetic processes have transformed the } \\
\text { original structural architecture of the sample. } \\
\text { Interpretation of the } 3 \text { Ps is compromised. } \\
\text { Diagenetic implications should be only formu- } \\
\text { lated in regard to second level of paleoenvi- } \\
\text { ronmental interpretations. }\end{array}$ \\
\hline
\end{tabular}

Table 1.- Suggestive procedure to separate diagenetic related features from true biological characters when confronted with abnormal eggshells.

Tabla 1.- Protocolo para separar los caracteres puramente biológicos de las características diagenéticas cuando estos se encuentran en cáscaras anormales

modify the structural composition of eggshells, which all in turn are cause to failed reproduction and if perpetrated could conceivably contribute to local and temporal extinctions. This aspect is particularly interesting in view that both Faidella and Auca Mahuevo nesting sites are close to the terminal Cretaceous, time at which non-avian dinosaurs progressively became extinct. The taxonomic aspect related to pathological eggshells rests on two levels of inferences and is based on the fact that some vertebrates according to the trophic levels in the food chain are more or less susceptible to chemical amplification. It is conceivable that a few dinosaur groups could selectively be more susceptible to a given "pollution" and produce pathological eggs. Hence, in similar ways that parasites selectively and taxonomically identify their hosts, pathological eggs would become typical of certain affected dinosaur groups during determined time periods. However and regardless of the paleo natural drivers, quantification of pathologies in respect to paleobiology, paleoenvironment, or taxonomy, should be adjusted with a guideline based on phylogenetic bracketing, i.e. from the pathological rates demonstrated between the two living crown groups that bracket extinct dinosaurs, the extant crocodilians and avians, under normal ecological conditions. 


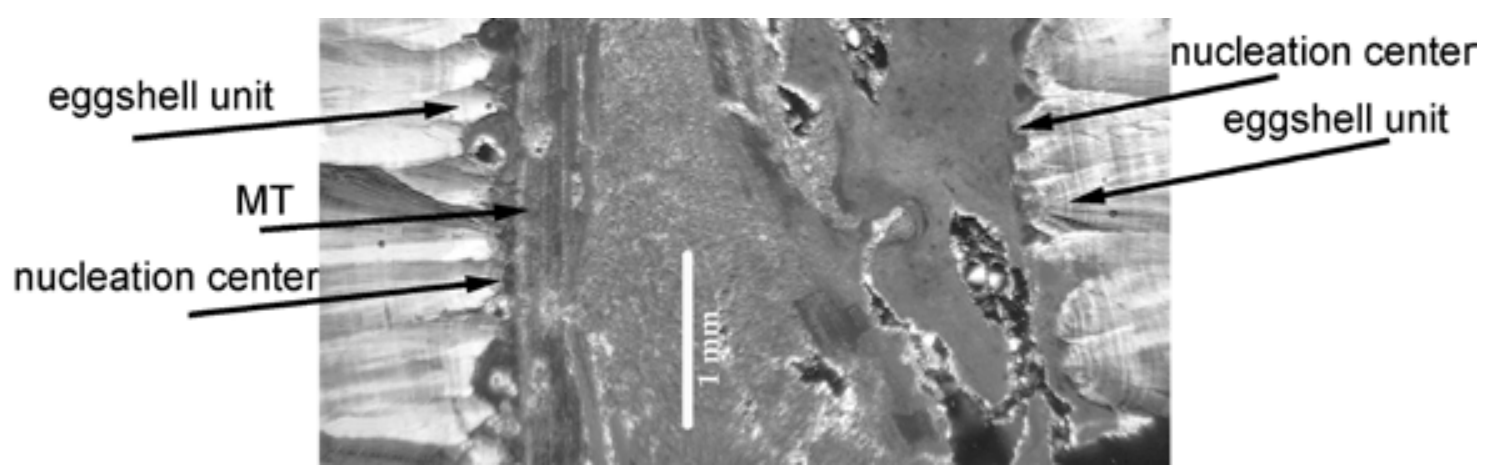

Fig. 5.- TLM view of two Auca Mahuevo eggshells cemented together. Note the presence of the membrana testácea (MT) in one eggshell and its absence in the other. This clearly indicates the extremely localized micro taphonomic and diagenetic environments present within one clutch and even one egg. It also illustrates the various and successive taphonomic and diagenetic stages that occurred and could foster abnormal eggshell structures during these processes.

Fig. 5.- Imagen TLM de dos cáscaras de huevo de Auca Mahuevo que han cementado juntas. Nótese que la membrana testácea (MT) está presente en una y ausente en la otra. Esto claramente muestra lo localizado que es el proceso tafonómico, a escala micro, de modo que incluso el ambiente diagenético se focaliza dentro de una puesta en un único huevo. Ello permite ilustrar los diferentes y sucesivos estadios diagenéticos que ocurrieron y que pudieron promover estructuras de cáscaras anormales a lo largo de estos procesos tan particulares.

\section{Conclusion}

The immediate consequences of these observations are clear: any eggshell structural artifact needs to be considered with caution, and multiple methods are required to assess the degree of alteration. CL and occasionally BSEM should be added to the arsenal of analytic and microscopic instruments to the study of eggshells, because of their ability to highlight areas of alteration not visible otherwise. Therefore, correctly evaluating the biological versus diagenetic features in the carbonate fossil record could only be accomplished by combining an array of observations and analyses. CL and BSEM followed by detailed PLM, TLM, and SEM observations should be performed particularly when erratic structures are observed to tease out the possible origins of these features, regardless of whether these alterations are the products of biomediation or not. Moreover, the final interpretations of whether an erratic structure is the product of diagenetic or biological processes stem from field observations and analytic procedures but also by adopting the simplest explanation(s) to why these features could be present in a given context. Consequently, unwarranted biological and evolutionary interpretations based on ad hoc hypotheses should be avoided. Conversely, true pathological eggs and their shells, when positively identified, could bring important data to paleobiological, paleoenvironmental and taxonomical related-issues.

\section{Acknowledgements}

G. Grellet-Tinner would like to acknowledge the Department of Earth Sciences at USC for its financial support and access to the carbonate laboratory for the duration of this investigation. A.D. Buscalioni is funded by Ministerio de Ciencia e Innovación CGL2009-11838 BTE. Comments by reviewers M.B. Muñoz and J.M. García are also greatly appreciated.

\section{References}

Amthor, J. (1993): Combining Cathodoluminescence and Backscattered Electron Microscoppy in the Study of Diagenetic Carbonates. Journal of Geological Education, 41: 140-143.

Ar, A., Paganelli, C. V., Reeves, R. B., Greene, D. G., Rahn, H. (1974): The avian egg: water vapor conductance, shell thickness, and functional pore area. The Condor, 76: 153-158. http://dx.doi. org/10.2307/1366725

Barbin, V. (2000): Cathodoluminescence of Carbonate Shells: Biochemicals vs. Diagenesis Processes. In M. Pagel, V. Barbin, and P. Blanc (eds.), Cathodoluminescence in Geosciences. Springer Press, Berlin: 303-329.

Board, G. B., Sparks, N. H. C. (1995): Avian Eggshell. In: C. D., Deeming, C.D., Ferguson, M. W. J. (eds.), Egg Incubation: its Effects on Embryonic Development in Birds and Reptiles. Cambridge University Press, New York: 71-86

Bottjer, D. J., Etter, W., Hagadorn, J. W., Tang, C. M. (2002): FossilLagerstätten: Jewels of the Fossil Record. In Bottjer, D. J., Etter, W., Hagadorn, J. W., Tang, C. M. (eds.), Exceptional Fossil Preservation. Cambridge University Press, New York.

Bravo, A. M., Moratalla, J. J. , Santafe, J. V., De Santisteban, C. (2000): Faidella, a new Upper Cretaceous nesting site from the Tremp basin (Lérida Province, Spain). First International Symposium on Dinosaur Eggs and Babies, Isona I Conca Dellà Catalonia: p. 15-22.

Bravo, A. M., Buscalioni, A. D., Merino, L., Müller, B. G. (2003): Experimental taphonomy of avian eggs and eggshells: effects on early diagenesis. Palaeovertebrata, 32(2-4): 77-95.

Chiappe, L. M., Coria, R. A., Dingus, L., Jackson, F., Chinsamy, A., Fox, M. (1998): Sauropod dinosaur embryos from the Late Cretaceous of Patagonia. Nature, 396: 258-261. 
Chiappe, L. M., Dingus, L., Jackson, F., Grellet-Tinner, G., Aspinall, R., Clarke, J., Coria, R., Garrido, A., Loope, D. (2000): Sauropod eggs and embryos from the Upper Cretaceous of Patagonia. First International Symposium on Dinosaur Eggs and Babies, Isona, Conca dellà Catalonia: p. 23-29.

Chiappe, L. M., Salgado, L., Coria, R. A. (2001): Embryonic skulls of titanosaur sauropod dinosaurs. Science, 293: 24442446. http://dx.doi.org/10.1126/science.1063723

Chiappe, L. M., Dingus, L. (2001): Walking on Eggs: the Astonishing Discovery of Thousands of Dinosaur Eggs in the Badlands of Patagonia. Scribner New York, 219 p.

Cousin, R. (1997): Les gisements d'oeufs de dinosauriens des Hautes Corbières et des Corbières Orientales (Aude): Ponte, nidification, microstructre des coquilles. Bulletin de la Société d'Études Scientifiques de l'Aude, XCVII: 29-46.

Cousin, R., Breton, G. (2000): A precise and complete excavation is necessary to demonstrate a dinosaur clutch structure: First International Symposium on Dinosaur Eggs and Babies, Isona I Conca Dellà Catalonia: p. 31-42.

Erben, H. (1970): Ultrastrukturen und Mineralisation rezenter und fossiler Eischalen bei Vögeln und Reptilien. Biomineralisation Forschungsberichte, 1: 1-66.

Ewert, M.A., Firth, S.J., Nelson, C.E. (1984): Normal and multiple eggshells in batagurine turtles and their implications for dinosaurs and other reptiles. Canadian Journal of Zoology, 62: 1834-1841. http://dx.doi.org/10.1139/z84-267

Deeming, C. D., Ferguson, M. W. J. (1995): Development in Birds and Reptiles. In: D. C. Deeming, M. W. J. Ferguson (eds.), Egg Incubation: Its Effects on Embryonic Development in Birds and Reptiles. Cambridge University Press, New York: 53-69.

Grellet-Tinner, G. (2005): The membrana testacea of titanosaurid dinosaur eggs from Auca Mahuevo (Argentina): Implications for the exceptional preservation of soft tissue in Lagerstätten. Journal of Vertebrate Paleontology, 25: 99-106. http://dx.doi. org/10.1671/0272-4634(2005)025[0099:MTOTDE]2.0.CO;2

Grellet-Tinner, G. (2006): Phylogenetic interpretation of eggs and eggshells: implications for phylogeny and Paleognathae phylogeny. Alcheringa, 30: 130-180. http://dx.doi. org/10.1080/03115510608619350

Grellet-Tinner, G., Norell, M. (2002): An avian egg from the Campanian of Bayn Dzak, Mongolia. Journal of Vertebrate Paleontology 22: 719-720. http://dx.doi.org/10.1671/02724634(2002)022[0719:AAEFTC]2.0.CO;2

Grellet-Tinner, G., Chiappe, L. M. (2004): Dinosaur eggs and nestings: implications for understanding the origin of birds In J. P. Currie, E. B. Koppelhus, M. A. Shugar, and J. L. Wright eds.), Feathered dragons: Studies on the Transition from dinosaurs to Birds. Indiana University Press, Bloomington, Indianapolis: 185-214.

Grellet-Tinner, G., Makovicky, P. J. (2006): A possible egg of the Theropod Deinonychus antirrhopus: Phylogenetic and biological implications. Canadian Journal of Earth Sciences, 43: 705719. http://dx.doi.org/10.1139/E06-033

Grellet-Tinner, G., Chiappe, L. M. Coria, R. (2004): Eggs of titanosaurid sauropods from the Upper Cretaceous of Auca Mahuevo (Argentina). Canadian Journal of Earth Sciences, 41: 949-960. http://dx.doi.org/10.1139/e04-049

Grellet-Tinner, G., Chiappe, L. M., Bottjer, D., Norell, M. (2006): Paleobiology of dinosaur eggs and nesting behaviors. Palaeogeography, Palaeoclimatology, Palaeoecology, 232: 294-321.
Hayward, J. M., Amlaner, C. J, Young, K. A. (1989): Turning eggs to fossils: a natural experiment in taphanomy. Journal of Vertebrate Paleontology, 9: 196-200. http://dx.doi.org/10.1080/0272 4634.1989.10011753

Hayward, J. M., Hirsch, K. F., and Robertson, T. C. (1991): Rapid dissolution of avian eggshells buried by Mount St. Helens ash. Palaios, 6: 174-178. http://dx.doi.org/10.2307/3514881

Jackson, F. D., Varricchio, D. J. (2003). Abnormal, multilayered eggshell in birds: implications for dinosaur reproductive anatomy. Journal of Vertebrate Paleontology, 23: 699-702. http:// dx.doi.org/10.1671/A1092

Jackson, F., Garrido, A., Schmitt, J., Chiappe, L. M., Dingus, L., Loope, D. B. (2004): Abnormal, multilayered titanosaur(Dinosauria: Suaropoda) eggs from in situ clutches at the Auca Mahuevo Locality, Neuquen Province, Argentina. Journal of Vertebrate Paleontology, 24(4): 913-922. http:// dx.doi.org/10.1671/0272-4634(2004)024[0913:AMTDSE]2.0. $\underline{\mathrm{CO} ; 2}$

Kérourio, P. (1981): Nouvelles observations sur le mode de nidification et de ponte chez les dinosauriens du Crétacé terminal du Midi de la France. Comptes Rendus Sommaires de la Société Geologique de France, 1: 25-28.

Kohring, R., Reitner, J. (1996): Interaction between Membrana Testacea and shell in fossil and modern eggs of amniotic vertebrates. Bulletin de l'Institut Océanographique de Monaco, Numéro spécial 14: 387-399.

López Martínez, N. (2000): Eggshell sites from the CretaceousTertiary transition in south-central Pyrenees (Spain). First International Symposium on Dinosaur Eggs and Babies, Isona I Conca Dellà Catalonia: p. 95-115.

Mikhailov, K. E. (1992): The Microstructure of Avian and Dinosaurian Eggshell: Phylogenetic Implications. In K. E. Campbell, Jr. (ed.), Papers in Avian Paleontology Honoring Pierce Brod$k o r b$. Natural History Museum of Los Angeles County, Science Series 36: 361-373.

Packard, M. J., DeMarco, V. G. (1995): Eggshell ultrastructure and formation in eggs of oviparous reptiles. In D. C. Deeming, and M. W. J. Ferguson (eds.), Egg Incubation: Its Effects on Embryonic Development in Birds and Reptiles. Cambridge University Press, New York: 53-69.

Pooley, A.S. (1979): Ultrastructural relationships of mineral and organic matter in avian eggshells. Scanning Electron Microscopy, 2: 475-482.

Schweitzer, M.H., Chiappe, L., Garrido, A.C., Lowenstein. J.M., Pincus, S.H. (2005): Molecular preservation in Late Cretaceous sauropod dinosaur eggshells. Proceedings of the Royal Society, B: 775-784. http://dx.doi.org/10.1098/rspb.2004.2876

Tucker, M. E., Wright, V. (1990): Carbonate Sedimentology. Balckwell Scientific Publications, Oxford, 482 p.

Vianey-Liaud, M., Mallan, P., Buscail, O., Montgelard, C. (1994): Review of French Dinosaur Eggshells: Morphology, Structure, Mineral, and Organic Composition. In K. Carpenter, K. F. Hirsch, and J. R. Horner (eds.), Dinosaur Eggs and Babies. Cambridge University Press, New York: 151-183.

Zeletnitsky, D., Therrien, F. (2008): Phylogenetic analysis of reproductive traits of maniraptoran theropods and its implications for egg parataxonomy. Palaeontology, 51: 807-816. 